\title{
Direct Protection Against Acetaminophen Hepatotoxicity by Propylthiouracil
}

\author{
IN VIVO AND IN VITRO STUDIES IN RATS AND MICE
}

\author{
Tadataka Yamada, Shelly ludwig, John Kuhlenkamp, and Neil Kaplowitz, \\ Gastroenterology Section, Medicine and Research Services, Veterans \\ Administration Wadsworth Medical Center, and University of California, Los \\ Angeles, California 90073
}

\begin{abstract}
A B S T RA C T Hepatotoxicity caused by acetaminophen can be prevented by enzyme-catalyzed conjugation of its reactive metabolite with glutathione (GSH). Since we have shown in previous studies that $6-\mathrm{N}$ propyl-2-thiouracil (PTU) can substitute for GSH as a substrate for the GSH $S$-transferases, we examined the possibility that PTU might also protect against acetaminophen hepatotoxicity by direct chemical interaction with the reactive metabolite of acetaminophen. In an in vitro system consisting of $\left[{ }^{3} \mathrm{H}\right]$ acetaminophen, liver microsomes from phenobarbital-pretreated rats, and an NADPH-generating system, we found that PTU had a dose-dependent additive effect with GSH on inhibition of acetaminophen covalent binding. PTU administration also resulted in a dose-dependent decrease in both GSH depletion and covalent binding in vivo in acetaminophen-treated mice. To examine the possible mechanisms by which PTU exerts its protective effect, we studied the action of PTU on both acetaminophen conjugation and metabolic activation. PTU had no effect upon acetaminophen pharmacokinetics in phenobarbital-pretreated rats, as examined by measuring acetaminophen concentration in bile, urine, and blood after an intraperitoneal dose, nor did it alter the total amount of polar conjugates formed. Microsomes from PTU-treated rats were unaltered in cytochrome P450 concentrations and $p$-nitroanisole-O-demethylase, benzo- $\alpha$-pyrene hydroxylase, and cytochrome $c$-reductase activities. Furthermore PTU did not decrease acetaminophen-GSH adduct formation in vitro, sug-
\end{abstract}

This work was presented in part to the American Association for the Study of Liver Diseases, 23 May 1979, New Orleans, La.

Dr. Yamada is a recipient of a Veterans Administration Research Associate Award.

Received for publication 15 April 1980 and in revised form 12 November 1980 gesting that there was no reduction in drug activation. However, in bile from $\left[{ }^{35} \mathrm{~S}\right] \mathrm{PTU}$ and $\left[{ }^{3} \mathrm{H}\right]$ acetaminophen treated rats, as well as in incubates of the two drugs with liver microsomes, a new ${ }^{35} \mathrm{~S}$ - and ${ }^{3} \mathrm{H}$-containing product could be identified. By both thin layer chromatography and high pressure liquid chromatography this new product, which co-eluted with $\left[{ }^{3} \mathrm{H}\right]-$ acetaminophen, was separated from unreacted $\left[{ }^{35} \mathrm{~S}\right]-$ PTU. The formation of this product in vitro was a function of PTU concentration and reached a maximum of $0.06 \mu \mathrm{mol} / \mathrm{min}$ per mg protein at $0.5 \mathrm{mM}$ PTU. In vivo, the total biliary excretion of this product over $4 \mathrm{~h}$ (116 nmol) equaled the net reduction in acetaminophen metabolite covalent binding in the liver of phenobarbital-pretreated rats $(108 \mathrm{nmol})$. We conclude that PTU, independent of its antithyroid effect, diminishes hepatic macromolecular covalent binding of acetaminophen reactive metabolite both in vivo and in vitro, and it does so by detoxifying the reactive metabolite through direct chemical interaction in a manner similar to GSH. These observations may define the mechanism by which PTU is protective against liver injury caused by acetaminophen.

\section{INTRODUCTION}

In recent years, acetaminophen hepatotoxicity has become a clinical problem of increasing frequency (1). The biochemical mechanism by which acetaminophen induces liver injury has been elucidated in detail (2-5) and has served as an important model in understanding the mechanisms of a wide variety of toxic drug hepatopathies. Although the bulk of ingested acetaminophen is metabolized in the liver by sulfation or glucuronidation to polar nontoxic metabolites (6), a minor metabolic pathway involves oxidation by cytochrome P-450 mixed function oxidases, resulting in the formation of a reactive metabolite which is detoxified 
by glutathione (GSH). ${ }^{1}$ The conjugation of this reactive metabolite of acetaminophen by GSH appears to be catalysed by an enzyme from liver cytosol, possibly a glutathione $S$-transferase (7). In the event of GSH depletion, such as might occur after a massive overdose of acetaminophen, the reactive metabolite may bind covalently to hepatic macromolecules with resultant hepatocellular necrosis. Treatment of acetaminophen hepatotoxicity has involved, therefore, the administration of GSH precursors such as cysteamine (8) and $N$ acetylcysteine (9).

6-N-Propyl-2-thiouracil (PTU) also has been shown to be protective against acetaminophen-induced liver necrosis (10) in addition to numerous other forms of experimental $(11,12)$ and clinical (13) toxic hepatopathy. The mechanism of this protection has been ascribed to the drug's antithyroid properties. Recently, however, we have found that PTU can substitute for GSH as a substrate in glutathione $S$-transferase catalyzed reactions (14). This observation has prompted us to study whether PTU might protect against acetaminophen hepatotoxicity through a direct biochemical mechanism rather than indirectly through its antithyroid activity. Our results suggest that PTU protects by forming a conjugate with the reactive metabolite of acetaminophen, much in the same manner as GSH.

\section{METHODS}

Chemicals. NADP, glucose-6-phosphate, glucose-6-phosphate dehydrogenase, GSH, acetaminophen, and benzo- $\alpha$-pyrene were obtained from Sigma Chemical Co. (St. Louis, Mo.). PTU was a gift of Eli Lilly and Co. (Indianapolis, Ind.). $p$ Nitroanisole was purchased from Aldrich Chemical Co., Inc. (Milwaukee, Wis.). $\left[{ }^{3} \mathrm{H}\right]$ acetaminophen (hydroxyacetanilide, $p-\left[{ }^{3} \mathrm{H}(\mathrm{G})\right], 3.54 \mathrm{Ci} / \mathrm{mmol}$ ) was obtained from New England Nuclear (Boston, Mass.) and [ $\left.{ }^{35} \mathrm{~S}\right] \mathrm{PTU}$ (6-N-propyl-2$\left[{ }^{35}\right.$ S]thiouracil, $109 \mathrm{mCi} / \mathrm{mmol}$ ) from Amersham Corp. (Arlington Heights, Ill.). All other chemicals used in this study were readily available commercial products.

In vitro covalent binding studies. Six male SpragueDawley rats weighing $250 \mathrm{~g}$ each were pretreated with phenobarbital $80 \mathrm{mg} / \mathrm{kg}$ i.p. daily in three divided doses for $3 \mathrm{~d}$. Phenobarbital has been shown in rats to be a necessary pretreatment to induce sufficient acetaminophen activation for hepatic necrosis to occur (2). The animals were killed, their livers excised, and their microsomes prepared by the method of Potter et al. (4). The protein concentration of the microsomes was assayed by the Lowry technique (15) using bovine serum albumin as a standard. Aliquots of microsomal suspension containing $2 \mathrm{mg}$ protein were incubated with $0.5 \mu \mathrm{Ci}$ $\left[{ }^{3} \mathrm{H}\right]$ acetaminophen $(0.04 \mu \mathrm{Ci} / \mu \mathrm{mol})$ in a final vol of $2.5 \mathrm{ml}$ of ice-cold $0.12 \mathrm{M}$ potassium phosphate $\mathrm{pH} 7.4$. The incubations were performed in the presence of $0.001,0.010,0.100$, and $1.000 \mathrm{mM} \mathrm{GSH}$ and in the presence or absence of $0.5 \mathrm{mM}$ PTU. After the incubation mixture was equilibrated at $37^{\circ} \mathrm{C}$ for $2 \mathrm{~min}, 0.5 \mathrm{ml}$ of a solution containing $1.15 \% \mathrm{KCl}, 30 \mathrm{mM}$ $\mathrm{MgCl}_{2}, 50 \mathrm{mM}$ glucose-6-phosphate, $1 \mathrm{U} / \mathrm{ml}$ glucose-6-phos-

${ }^{1}$ Abbreviations used in this paper: GSH, glutathione; PTU, 6-N-propyl-2-thiouracil. phate dehydrogenase, and $2 \mathrm{mM}$ NADP was added and the samples were mixed in a Dubnoff shaking incubator for 30 min at $37^{\circ} \mathrm{C}$. The reactions were stopped by adding $0.8 \mathrm{ml}$ of trichloroacetic acid and vortexing. The samples were centrifuged at $2,000 \mathrm{~g}$ for $15 \mathrm{~min}$ at $4^{\circ} \mathrm{C}$, the supernates were decanted, and the pellets were washed sequentially with $2 \mathrm{ml}$ of $0.6 \mathrm{M}$ trichloroacetic acid once and $2 \mathrm{ml}$ of absolute methanol until no further radioactivity could be detected in the supernates when added to $10 \mathrm{ml}$ Aquasol-II (New England Nuclear) and counted in a liquid scintillation spectrometer (an average of nine washes). The remaining radioactivity was considered covalently bound to the microsomal protein and was counted after dissolving the pellet in $1 \mathrm{ml}$ of $1 \mathrm{~N} \mathrm{NaOH}$ at $25^{\circ} \mathrm{C}$ for $16 \mathrm{~h}$. To study the effect of PTU concentration on microsomal covalent binding by acetaminophen-reactive metabolite, liver microsomes fron phenobarbital pretreated rats that had been dosed with 0 or $150 \mathrm{mg} / \mathrm{kg}$ PTU $30 \mathrm{~min}$ before killing ( $n=4$ in each group) were incubated and processed as detailed above except in the presence of one concentration of GSH $(0.01 \mathrm{mM})$ and four different concentrations of PTU $(0,0.1,0.3$, and $0.5 \mathrm{mM})$. The initial trichloroacetic acid supernates from the samples were analyzed by high pressure liquid chromatography to determine the influence of PTU on the formation of GSH-acetaminophen conjugate as well as to measure the formation of PTU-acetaminophen conjugate as a function of PTU concentration. GSH-acetaminophen conjugate was assayed using the method of Buckpitt et al. (16) and details of the PTU-acetaminophen conjugate chromatography are given below.

In vivo studies. Mice were used for in vivo studies because of their greater susceptibility to the hepatotoxic effect of acetaminophen as compared to rats (2). Three groups of 32 male Swiss Weiss mice (weighing 20-30 g each) were injected intraperitoneally with 0,3 , or $30 \mathrm{mg} / \mathrm{kg}$ PTU dissolved in $0.1 \mathrm{ml}$ ethanol, and $30 \mathrm{~min}$ later, each group was divided into four subgroups of eight mice each to which $0,250,500$, or $750 \mathrm{mg} / \mathrm{kg}$ acetaminophen i.p. was administered. The acetaminophen was first dissolved in water at $70^{\circ} \mathrm{C}$ then cooled to $37^{\circ} \mathrm{C}$ for administration. After $4 \mathrm{~h}$ the animals were killed and their livers homogenized in a motor-driven glass-Teflon tissue homogenizer (Dupont Instruments, Wilmington, Del.) with two parts (vol/wt) $0.1 \mathrm{M}$ sodium phosphate, $0.25 \mathrm{M}$ sucrose buffer, $\mathrm{pH}$ 7.4. The homogenates were assayed for GSH concentration by reacting with $5,5^{\prime}$-dithiobis (2-nitrobenzoic acid) and measuring absorbance at $412 \mathrm{~nm}$ according to the method of Owens and Belcher (17) as modified by Kaplowitz (18). PTU itself did not react with the reagent.

Three additional groups of eight mice each were pretreated with 0,3 , or $30 \mathrm{mg} / \mathrm{kg}$ PTU followed in $30 \mathrm{~min}$ by $750 \mathrm{mg} / \mathrm{kg}$ $\left[{ }^{3} \mathrm{H}\right]$ acetaminophen $(4 \mu \mathrm{Ci} / \mathrm{mmol}) .4 \mathrm{~h}$ later, at the time of peak covalent binding (3), the animals were killed after withdrawing a sample of blood. The blood was assayed for ${ }^{3} \mathrm{H}$, liver were homogenized, and assayed for $\left[{ }^{3} \mathrm{H}\right]$ acetaminophen metabolite covalent bindings as described above and for unconjugated acetaminophen by measuring ethylacetateextractable ${ }^{3} \mathrm{H}(19)$.

The effect of PTU on the pharmacokinetics of acetaminophen was studied by measuring the concentration of $\left[{ }^{3} \mathrm{H}\right]-$ acetaminophen in the blood, urine, and bile of two groups of six phenobarbital pretreated rats $(80 \mathrm{mg} / \mathrm{kg}$ per $\mathrm{d}$ for $3 \mathrm{~d}$ ). The rats were anesthetized with pentobarbital $50 \mathrm{mg} / \mathrm{kg}$, placed on heated operating boards, and their left external jugular veins, left femoral arteries, common bile ducts, and urinary bladders were cannulated. Sodium chloride $(0.15 \mathrm{M})$ was infused via the jugular vein at a rate of $2 \mathrm{ml} / \mathrm{kg}$ per h. Six rats were injected with $150 \mathrm{mg} / \mathrm{kg}$ PTU in ethanol $(0.1 \mathrm{ml})$ and six were treated with vehicle alone. After $30 \mathrm{~min}$, each rat was injected with $500 \mathrm{mg} / \mathrm{kg}\left[{ }^{3} \mathrm{H}\right]$ acetaminophen $(8 \mu \mathrm{Ci} / \mathrm{mmol})$. 
Samples of urine, blood, and bile were extracted with ethyl acetate and the extracts were assayed for ${ }^{3} \mathrm{H} 60,120,180$, and $240 \mathrm{~min}$ later. The bile and urine samples were later assayed for PTU-acetaminophen conjugate concentration as noted below.

In another study, two groups of 10 phenobarbital pretreated rats were administered 0 or $150 \mathrm{mg} / \mathrm{kg}\left[{ }^{35} \mathrm{~S}\right] \mathrm{PTU}(3.4 \mu \mathrm{Ci} /$ $\mathrm{mmol})$. After $30 \mathrm{~min}$, the groups were divided into subgroups of five rats treated with 0 or $750 \mathrm{mg} / \mathrm{kg}\left[{ }^{3} \mathrm{H}\right]$ acetaminophen $(8 \mu \mathrm{Ci} / \mathrm{mmol})$. Bile was collected for $4 \mathrm{~h}$, after which the animals were killed and $\left[{ }^{3} \mathrm{H}\right]$ acetaminophen covalent binding to whole liver homogenate was assayed. Bile samples were applied to thin layer chromatography as described below and $\left.{ }^{35} \mathrm{~S}\right] \mathrm{PTU}$ eluting as new product was estimated. The cytochrome P-450 concentration of microsomes prepared from these rats was measured by the method of Omura and Sato (20) and cytochrome P-450 activity was quantified by measuring $p$-nitroanisole-O-demethylase activity (21). Cytochrome $\mathrm{P}_{1}-450$ activity was assayed by measuring benzo- $\alpha$-pyrenehydroxylase activity $(22)$ and cytochrome $c$-reductase activity was measured by the method of Williams and Kamin (23).

Identification of PTU-acetaminophen conjugate. Bile and liver homogenate samples from the rats used in the pharmacokinetic studies as well as the initial trichloroacetic acid supernates from in vitro covalent binding studies using $\left[{ }^{3} \mathrm{H}\right]$ acetominophen and $\left[{ }^{35} \mathrm{~S}\right] \mathrm{PTU}$ were analyzed for the presence of a PTU-acetaminophen conjugate. Aliquots $(50 \mu \mathrm{l})$ of sample, $\left[{ }^{3} \mathrm{H}\right]$ acetominophen, and $\left[{ }^{35} \mathrm{~S}\right] \mathrm{PTU}$ were spotted on silica gel thin layer chromatography plates $(20 \times 20 \mathrm{~cm})$, air-dried, and chromatographed with a chloroform/benzene/methanol (3:1:1) solvent system. Sections of the plates $(1 \mathrm{~cm})$ were scraped into test tubes, vortexed with hot distilled water, and centrifuged at $2,000 \mathrm{~g}$ for $5 \mathrm{~min}$. Aliquots $(0.5 \mathrm{ml})$ of the supernates were added to $10 \mathrm{ml}$ Aquasol-II and counted for both ${ }^{3} \mathrm{H}$ and ${ }^{35} \mathrm{~S}$ simultaneously in a liquid scintillation spectrometer. In addition $20-\mu \mathrm{l}$ aliquots of trichloracetic acid supernate from in vitro covalent binding studies using $\left[{ }^{3} \mathrm{H}\right]$ acetaminophen and $\left[{ }^{35} \mathrm{~S}\right] \mathrm{PTU}$ were neutralized and applied to to a $\mu \mathrm{B}$ ondapak $\mathrm{C}-18$ high pressure liquid chromatography column $(0.4 \times 25 \mathrm{~cm}$, Altex Scientific, Inc., Berkeley, Calif.) which was equilibrated with $30 \%$ acetonitrile and eluted according to the following protocol: $30 \%$ acetonitrile for $4 \mathrm{~min}$, $30-100 \%$ over $3 \mathrm{~min}$, and $100 \%$ for $5 \mathrm{~min}$. The flow rate was $2 \mathrm{ml} / \mathrm{min}$ and eluted fractions were collected at $0.5-\mathrm{min}$ intervals and assayed for both ${ }^{3} \mathrm{H}$ and ${ }^{35} \mathrm{~S} .\left[{ }^{3} \mathrm{H}\right]$ Acetaminophen standard had a retention time of $5.5 \mathrm{~min}$ and $\left[{ }^{35} \mathrm{~S}\right] \mathrm{PTU}$ standard eluted at $8.0 \mathrm{~min}$. All liquid scintillation counting was performed in a Beckman LS-3150T liquid scintillation spectrometer (Beckman Instruments, Inc., Fullerton, Calif.) using external standardization for quench correction. Double isotope $\left({ }^{3} \mathrm{H}\right.$ and $\left.{ }^{35} \mathrm{~S}\right)$ counting was performed by setting windows so that ${ }^{3} \mathrm{H}$ had no crossover into the ${ }^{35} \mathrm{~S}$ channel. ${ }^{35} \mathrm{~S}$ crossover into the ${ }^{3} \mathrm{H}$ channel was corrected for by using appropriate control standards. The automatic quench compensator was used to minimize crossover of ${ }^{35} \mathrm{~S}$.

Statistics. All statistical comparisons were made using Student's $t$ test for analysis. Unless otherwise noted, a $P$ value of $<0.05$ was accepted as significant.

\section{RESULTS}

Covalent binding of $\left[{ }^{3} \mathrm{H}\right]$ acetaminophen reactive metabolite to rat liver microsomes in vitro decreased with increasing GSH concentration (Fig. 1) as noted previously by Mitchell et al. (5). However, at any given GSH concentration the presence of PTU $(0.5 \mathrm{mM})$ significantly decreased the amount of covalent binding

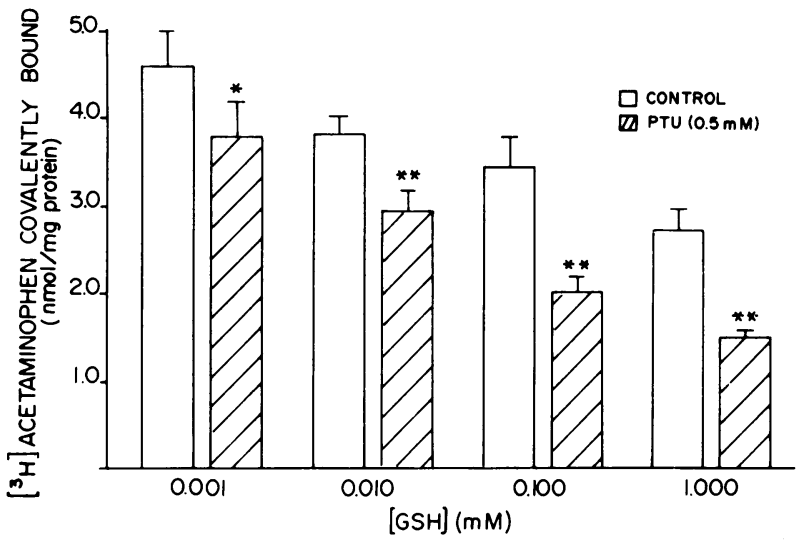

Figure 1 Inhibition of $\left[{ }^{3} \mathrm{H}\right]$ acetaminophen covalent binding to rat liver microsomes in vitro by PTU at varying GSH concentrations. Microsomes ( $2 \mathrm{mg}$ protein) from each of six phenobarbital pretreated rats were incubated for $30 \mathrm{~min}$ at $37^{\circ} \mathrm{C}$ with $0.5 \mu \mathrm{Ci}\left[{ }^{3} \mathrm{H}\right]$ acetaminophen $(0.04 \mu \mathrm{Ci} / \mu \mathrm{mol}), \mathrm{GSH}$ $(0.001-1.000 \mathrm{mM})$, PTU (0 or $0.5 \mathrm{mM})$, and an NADPH generating system. The reaction was stopped and microsomal proteins were precipitated by the addition of trichloroacetic acid. After a subsequent wash with trichloroacetic acid, the precipitates were washed with methanol repeatedly until no further radioactivity could be eluted. The remaining radioactivity was considered covalently bound and was counted after dissolving the precipitate in $1 \mathrm{~N} \mathrm{NaOH}$. Results are depicted as mean $\pm \mathrm{SE}$. A progressive decline was noted in covalently bound $\left[{ }^{3} \mathrm{H}\right]$ acetaminophen with increasing GSH concentration. At each GSH concentration, PTU significantly decreased covalent binding. $* P<0.05 ; * * P<0.01$.

even further. This protective effect of PTU, when studied at a single GSH concentration $(0.1 \mathrm{mM})$ was dose dependent, as is shown in Fig. 2. Thus, in this system PTU appears to have a dose-dependent effect

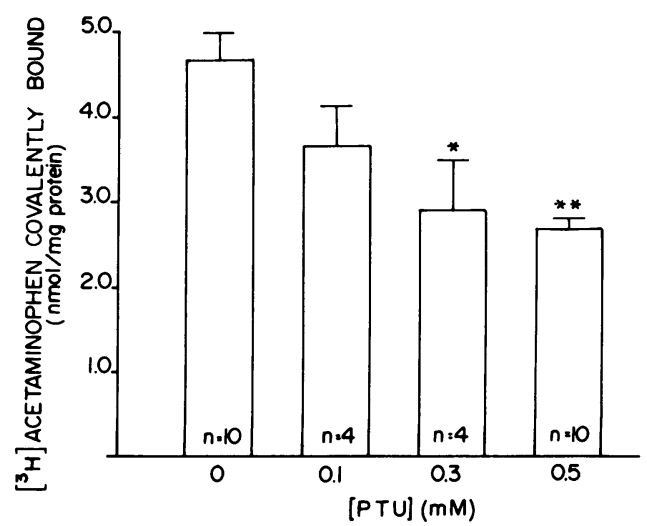

Figure 2 Dose-dependent inhibition of $\left[{ }^{3} \mathrm{H}\right]$ acetaminophen covalent binding to rat liver microsomes in vitro by PTU. Using the same microsomal incubation system described in Fig. 1 but at only one concentration of GSH $(0.01 \mathrm{mM})$ and varying concentrations of PTU $(0,0.1,0.3$, and $0.5 \mathrm{mM})$ the covalent binding of $\left[{ }^{3} \mathrm{H}\right]$ acetaminophen to microsomal proteins was measured. Results are depicted as mean \pm SE. PTU had a dose-dependent inhibitory effect on covalent binding that was significant at the two highest concentrations of drug. $* P<0.02 ; * * P<0.001$. 


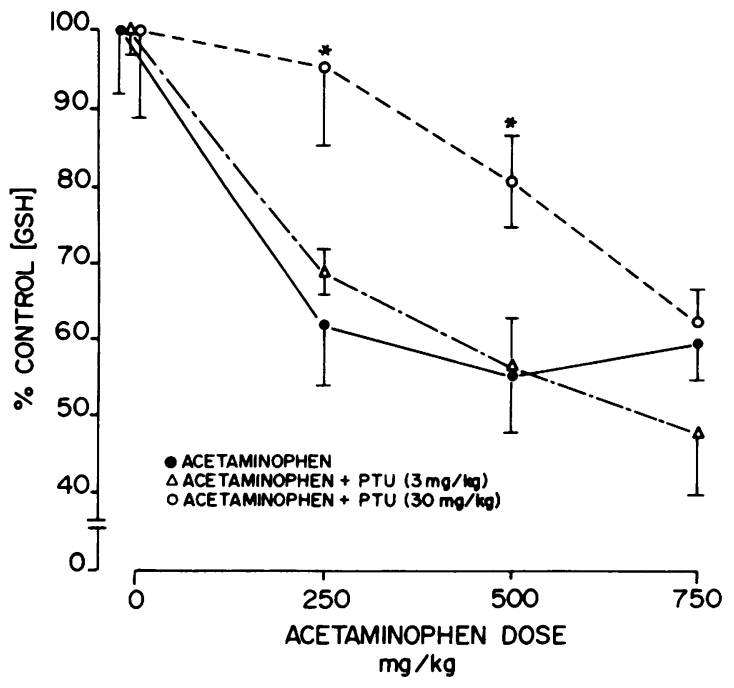

FIGURE 3 Inhibition of acetaminophen-induced mouse hepatic GSH depletion by pretreatment with PTU. Groups of 32 mice were treated with 0,3 , or $30 \mathrm{mg} / \mathrm{kg}$ PTU. $30 \mathrm{~min}$ later, the groups were divided into subgroups of eight mice each, which were treated with $0,250,500$, or $750 \mathrm{mg} / \mathrm{kg}$ acetaminophen. After $4 \mathrm{~h}$, the mice were killed and their livers homogenized and assayed for GSH. Results are depicted as mean \pm SE. PTU at the highest dose inhibited acetaminopheninduced GSH depletion at the 250 and $500 \mathrm{mg} / \mathrm{kg}$ doses of acetaminophen. This GSH-sparing effect of PTU was overcome at the $750 \mathrm{mg} / \mathrm{kg}$ dose of acetaminophen. $* P<0.03$.

which is additive with respect to the effect of GSH in protecting against covalent binding of acetaminophen metabolite to liver microsomes.

This interaction between PTU and GSH was further studied in vivo in mice as shown in Fig. 3. At the low dose ( $3 \mathrm{mg} / \mathrm{kg}$ ) PTU was ineffective in preventing acetaminophen-induced GSH depletion. However, PTU at the high dose $(30 \mathrm{mg} / \mathrm{kg})$ prevented GSH depletion induced by acetaminophen at the 250 and $500 \mathrm{mg} / \mathrm{kg}$ dose. Even this protective effect could be overcome if a large enough dose of acetaminophen $(750 \mathrm{mg} / \mathrm{kg})$ was administered. Nevertheless PTU protection against covalent binding of acetaminophen administered at this dose was observed as shown in Fig. 4. Although low dose PTU was without measurable effect, high dose PTU significantly diminished acetaminophen covalent binding, thus confirming in vivo the in vitro observations noted above.

We next directed our efforts at determining the mechanism by which PTU exerts this protection against acetaminophen covalent binding. One possible explanation for this phenomenon might be interference with metabolic activation of acetaminophen. Table I summarizes the experimental evidence that we have derived to examine this possibility. In short-term acute studies, neither PTU nor acetaminophen had significant effects on cytochrome P-450 concentration or activity, cytochrome $\mathrm{P}_{1}-450$ activity, or cytochrome $c$-re-

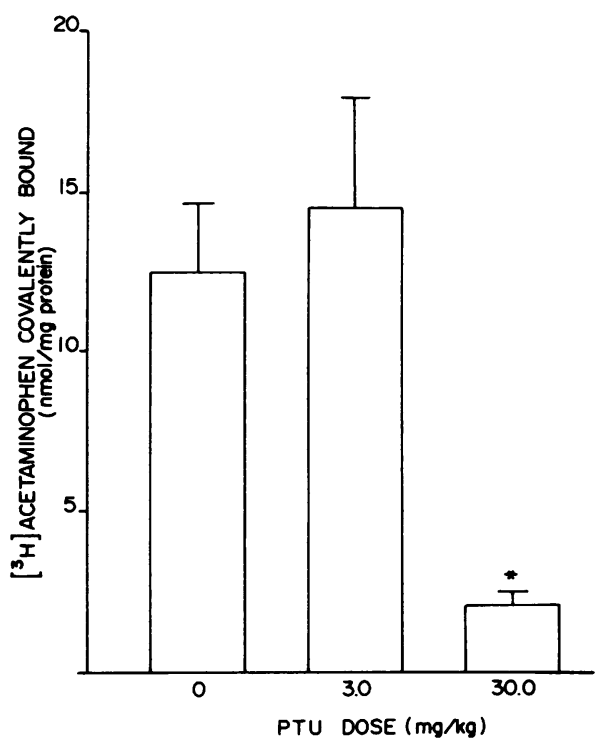

FIGURE 4 Inhibition of $\left[{ }^{3} \mathrm{H}\right]$ acetaminophen covalent binding to mouse liver proteins in vivo by treatment with PTU. Three groups of eight mice each were treated with 0,3 , or 30 $\mathrm{mg} / \mathrm{kg}$ PTU followed in $30 \mathrm{~min}$ by $750 \mathrm{mg} / \mathrm{kg}\left[{ }^{3} \mathrm{H}\right]$ acetaminophen. $4 \mathrm{~h}$ later, the mice were killed and their liver homogenates were assayed for $\left[{ }^{3} \mathrm{H}\right]$ acetaminophen covalent binding as described in Fig. 1. Results are depicted as mean \pm SE. PTU at the $30 \mathrm{mg} / \mathrm{kg}$ dose significantly inhibited covalent binding. $* P<0.001$.

ductase activity. Furthermore, PTU had no effect on GSH-acetaminophen conjugate formation in vitro using the microsomal test system, implying that it had no inhibitory effect on acetaminophen reactive metabolite formation specifically (Table II). PTU exerted no influence on serum or hepatic ethylacetate-extractable acetaminophen concentrations in the mice administered $750 \mathrm{mg} / \mathrm{kg}$ acetaminophen described above (Table III), suggesting that PTU did not alter overall acetaminophen metabolism or acetaminophen conjugate formation. Lastly, PTU had no influence on the pharmacokinetics of acetaminophen in blood, urine, or bile of rats, as depicted in Fig. 5.

We studied the remaining possibility that PTU forms a direct conjugate with acetaminophen reactive metabolite. Using both a thin layer chromatography system (Fig. 6) and a high pressure liquid chromatography system (data not shown) we were able to clearly separate $\left[{ }^{3} \mathrm{H}\right]$ acetaminophen from $\left[{ }^{35} \mathrm{~S}\right] \mathrm{PTU}$. After reaction of $\left[{ }^{3} \mathrm{H}\right]$ acetaminophen with $\left[{ }^{35} \mathrm{~S}\right] \mathrm{PTU}$ in vivo or in vitro in the presence of liver microsomes and an NADPH-generating system, a new peak of ${ }^{35} \mathrm{~S}$ radioactivity could be found that coincided with the unreacted $\left[{ }^{3} \mathrm{H}\right]$ acetaminophen peak (seen in both chromatography systems), suggesting the formation of a $\left[{ }^{3} \mathrm{H}\right]$ acetaminophen $-\left[{ }^{35} \mathrm{~S}\right] \mathrm{PTU}$ conjugate. This new product was never observed in the absence of acetaminophen or liver microsomes. The amount of new 
TABLE I

Effect of PTU and Acetaminophen Administration on Microsomal Drug-metabolizing Enzymes in Rats

\begin{tabular}{|c|c|c|c|c|}
\hline Treatment group & Cytochrome P-450 & $\begin{array}{l}p \text {-Nitroanisole- } \\
O \text {-demethylase }\end{array}$ & $\begin{array}{l}\text { Cytochrome } \\
c \text { reductase }\end{array}$ & $\begin{array}{c}\text { Benzo- } \alpha \text {-pyrene } \\
\text { hydroxylase }\end{array}$ \\
\hline & nmol/mg protein & $\mathrm{nmol} / \mathrm{min} / \mathrm{mg}$ & nmol/min/mg & relative activity/mg \\
\hline 0 PTU & & & & \\
\hline 0 Acetaminophen & $0.86 \pm 0.07$ & $0.90 \pm 0.13$ & $71.0 \pm 4.6$ & $0.44 \pm 0.02$ \\
\hline 150 PTU & & & & \\
\hline 0 Acetaminophen & $0.73 \pm 0.09$ & $0.90 \pm 0.12$ & $70.9 \pm 4.5$ & $0.41 \pm 0.03$ \\
\hline 0 PTU & & & & \\
\hline 750 Acetaminophen & $0.83 \pm 0.05$ & $1.06 \pm 0.16$ & $67.6 \pm 6.5$ & $0.46 \pm 0.02$ \\
\hline 150 PTU & & & & \\
\hline 750 Acetaminophen & $0.86 \pm 0.06$ & $0.87 \pm 0.04$ & $80.4 \pm 3.3$ & $0.40 \pm 0.02$ \\
\hline
\end{tabular}

Two groups of 10 phenobarbital pretreated rats were administered 0 or $150 \mathrm{mg} / \mathrm{kg}$ PTU. After $30 \mathrm{~min}$ the rats were divided into two subgroups of five rats which were treated with 0 or $750 \mathrm{mg} / \mathrm{kg}$ acetaminophen. $4 \mathrm{~h}$ later the rats were killed and their liver microsomes assayed for cytochrome P-450 content and $p$-nitroanisole$O$-demethylase, cytochrome $c$-reductase, and benzo- $\alpha$-pyrene hydroxylase activities. Means $\pm \mathrm{SE}$ are recorded in the table.

product formed in vitro was a function of PTU concentration, reaching a maximum of $0.06 \mu \mathrm{mol} / \mathrm{min}$ per $\mathrm{mg}$ protein at $0.5 \mathrm{mM}$ PTU. To determine the physiologic significance of this possible new reaction product, the net reduction in acetaminophen covalent binding to whole liver homogenate in vivo produced by treatment with $\left[{ }^{35}\right.$ S]PTU was compared to the total excretion of $\left[{ }^{35}\right.$ S]PTU as "new" reaction product separated by thin layer chromatography. As shown in Fig. 7, the reduction in covalent binding in PTU-treated rats $(108 \mathrm{nmol})$

TABLE II

Effect of PTU on Acetaminophen-GSH Adduct Formation in vitro

\begin{tabular}{lcccc}
\hline \multicolumn{2}{c}{ Untreated rat microsomes } & & \multicolumn{2}{c}{ PTU pretreated rat microsomes } \\
\cline { 5 - 5 } [PTU] & $\begin{array}{c}\text { GSH-acetaminophen } \\
\text { adduct formed }\end{array}$ & & [PTU] & $\begin{array}{c}\text { GSH-acetaminophen } \\
\text { adduct formed }\end{array}$ \\
\hline$m M$ & nmol & & $m M$ & nmol \\
0 & $21 \pm 5$ & 0 & $18 \pm 3$ \\
0.5 & $16 \pm 3$ & 0.5 & $17 \pm 4$ \\
\hline
\end{tabular}

Liver microsomes $(2 \mathrm{mg}$ protein) from phenobarbital pretreated rats that had been administered 0 or $150 \mathrm{mg} / \mathrm{kg}$ PTU ( $n=4$ in each group) $30 \mathrm{~min}$ before killing were incubated for $60 \mathrm{~min}$ at $37^{\circ} \mathrm{C}$ with $0.5 \mu \mathrm{Ci}\left[{ }^{3} \mathrm{H}\right]$ acetaminophen $(0.04$ $\mu \mathrm{Ci} / \mu \mathrm{mol}), 0.01 \mathrm{mM} \mathrm{GSH}$, and PTU $(0$ or $0.5 \mathrm{mM})$ in the presence of an NADPH generating system. The reaction was stopped and microsomal proteins were precipitated for the addition of trichloroacetic acid. The supernates were assayed for acetaminophen-GSH conjugate formation by the method of Buckpitt (16). Results are expressed as mean \pm SE. closely approximates the total biliary excretion of $\left[{ }^{35} \mathrm{~S}\right]-$ PTU as new product $(116 \mathrm{nmol})$. No new product was observed in the urine. These data suggest that formation of a PTU-acetaminophen conjugate may account quantitatively for the decreased hepatic covalent bindings of acetaminophen in PTU-treated rats.

\section{DISCUSSION}

The mechanism of acetaminophen hepatotoxicity has been ascribed to the covalent binding of hepatic macro-

TABLE III

Effect of PTU on Metabolism of Acetaminophen in Mice

\begin{tabular}{ccc}
\hline \multirow{2}{*}{ PTU dose } & \multicolumn{2}{c}{$\left[{ }^{3} \mathrm{H}\right]$ Acetaminophen concentration } \\
\cline { 2 - 3 } & Serum & Liver \\
\hline $\mathrm{mg} / \mathrm{kg}$ & $\mu \mathrm{mol} / \mathrm{ml}$ & $\mu$ mol/mg protein \\
& $252 \pm 48$ & $22.0 \pm 4.6$ \\
3 & $261 \pm 42$ & $25.2 \pm 5.4$ \\
30 & $254 \pm 38$ & $29.6 \pm 6.7$ \\
\hline
\end{tabular}

Three groups of eight mice each were treated with 0,3 , or $30 \mathrm{mg} / \mathrm{kg}$ PTU followed in $30 \mathrm{~min}$ by $750 \mathrm{mg} / \mathrm{kg}\left[{ }^{3} \mathrm{H}\right]$ acetaminophen. $4 \mathrm{~h}$ later the mice were killed after withdrawing a serum sample and their livers were homogenized. Ethyl acetate-extractable (unmetabolized) $\left[{ }^{3} \mathrm{H}\right]$ acetaminophen concentrations in both serum and liver homogenate samples were assayed. PTU had no significant effect, indicating that it did not alter overall metabolism of acetaminophen. Means $\pm \mathrm{SE}$ are recorded on the table. 


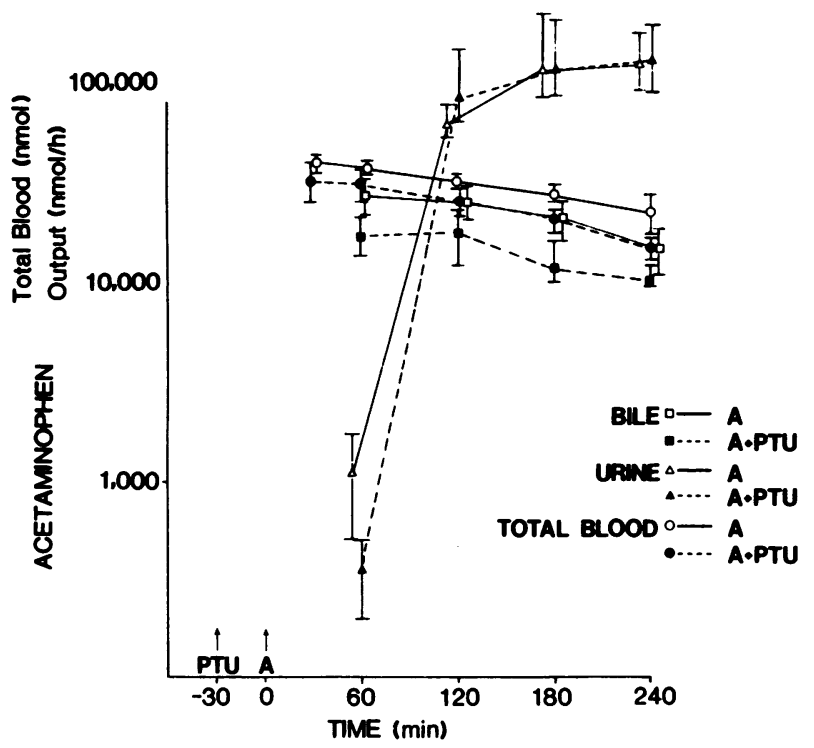

FIGURE 5 Effect of PTU on the concentrations of $\left[{ }^{3} \mathrm{H}\right]$ acetaminophen (A) in the bile, urine, and blood of phenobarbital pretreated rats. Two groups of six pentobarbital-anesthetized rats each were treated with 0 or $150 \mathrm{mg} / \mathrm{kg}$ PTU followed in $30 \mathrm{~min}$ by $\left[{ }^{3} \mathrm{H}\right]$ acetaminophen $500 \mathrm{mg} / \mathrm{kg}$. Samples of bile, urine, and blood were collected at $60,120,180$, and $240 \mathrm{~min}$, extracted in ethyl acetate, and the extracts were counted for ${ }^{3} \mathrm{H}$. Results are plotted on a semilogarithmic scale and depicted as mean \pm SE. PTU had no significant effect on $\left[{ }^{3} \mathrm{H}\right]-$ acetaminophen concentrations.

molecules by a reactive metabolite of the drug (3). We have confirmed both in vitro and in vivo the observations of Mitchell et al. (5) that the amount of covalent binding of acetaminophen metabolite is inversely related to the concentration of GSH, a potent nucleophile that detoxifies the metabolite by forming a conjugate with it. This conjugation in vitro has been shown to be catalyzed by a cytosolic enzyme, presumably a glutathione $S$-transferase (7). Our previous studies showing that PTU is a substrate for the glutathione S-transferases that substitutes for GSH (14) prompted us to examine the effect of PTU on hepatocyte macromolecular covalent binding by acetaminophen reactive metabolite. We found in vitro that PTU had a dose-dependent protective effect that was additive with the effect of GSH. In vivo, PTU not only decreased covalent binding but also prevented hepatic GSH depletion by acetaminophen.

Previous in vivo studies of acetaminophen toxicity by Linscheer et al. (10) have suggested that the protective effect of PTU is mediated by its antithyroid activity, much in the same manner as has been postulated for its beneficial effect in alcoholic liver disease (24). However, both our in vitro and short term in vivo studies showing the protective effect of PTU against hepatocyte macromolecular covalent binding by acetaminophen reactive metabolite indicate that PTU acts, at
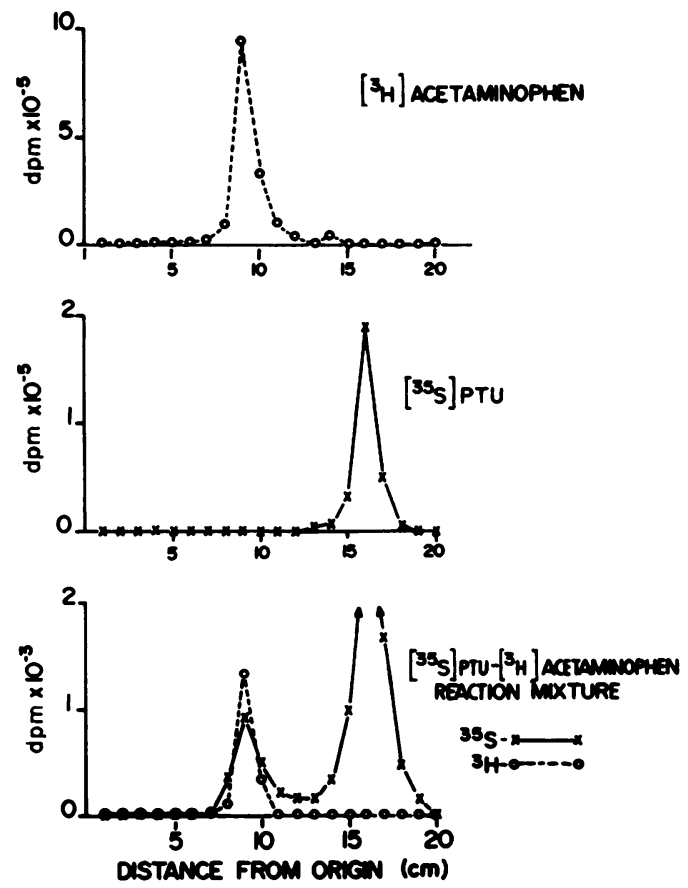

FIgURE 6 Thin layer chromatography of $\left[{ }^{3} \mathrm{H}\right]$ acetaminophen, $\left[{ }^{35} \mathrm{~S}\right] \mathrm{PTU}$, and $\left[{ }^{35} \mathrm{~S}\right] \mathrm{PTU}-\left[{ }^{3} \mathrm{H}\right]$ acetaminophen reaction mixture using a chloroform/benzene/methanol (3:1:1) solvent system for elution. Sections $(1 \mathrm{~cm})$ were scraped from the $20 \times 20$ plates, eluted with hot water, and counted for ${ }^{3} \mathrm{H}$, ${ }^{35} \mathrm{~S}$, or both. A new ${ }^{35} \mathrm{~S}$ peak could be separated in the reaction mixture that was separate from the [ ${ }^{35}$ S]PTU peak but that coeluted with the $\left[{ }^{3} \mathrm{H}\right]$ acetaminophen peak.

least in part, independently of its antithyroid effect. More recent studies, also by Linscheer et al. (25), showing that triiodothyronine treatment had no effect upon the protective action of PTU against acetaminophen hepatotoxicity confirm our observations.

We reasoned that the mechanism of PTU action could be explained by $(a)$ increased conjugation of acetaminophen by the usual mechanisms of sulfation or glucuronidation, $(b)$ decreased metabolic activation by microsomal drug metabolizing enzymes, or $(c)$ substitution of PTU for GSH in detoxification of acetaminophen reactive metabolite. Slattery and Levy (26) have suggested that sulfation and glucuronidation of acetaminophen are capacity-limited processes, whereas formation of reactive metabolite follows first-order kinetics. Thus, thiols such as $\mathrm{N}$-acetylcysteine, which have been shown to be effective against acetaminophen toxicity, may act by serving as sources of inorganic sulfate, the availability of which is rate-limiting, rather than as GSH precursors (27). Although it is conceivable that PTU might be acting in a similar manner, our data suggest the contrary since PTU had no effect upon overall pharmacokinetics, metabolism, or conjugation of acetaminophen. Certain thionosulfur-containing compounds, including PTU, have been shown to inhibit 

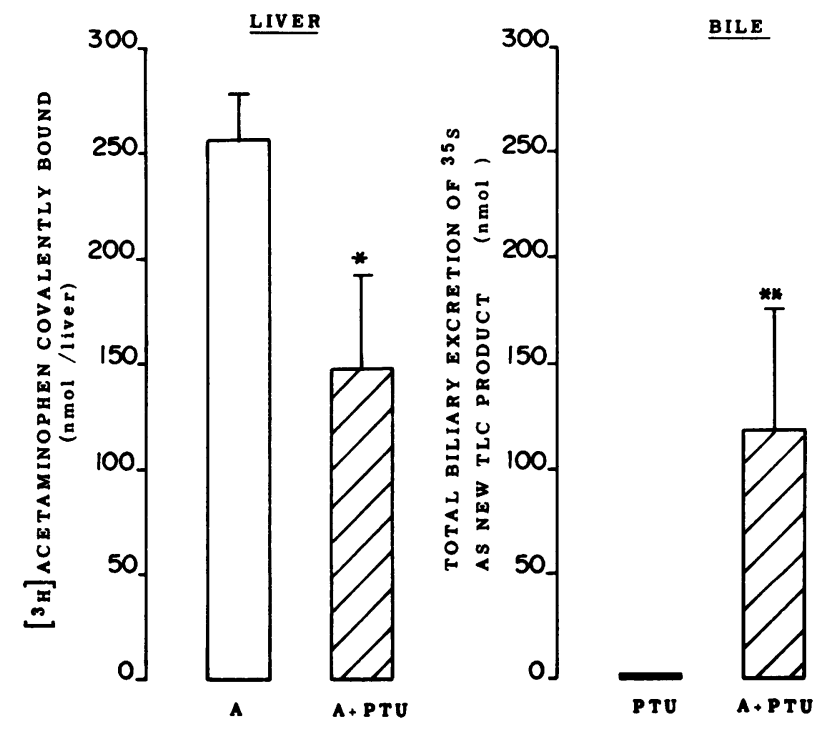

FIgURE 7 Comparison of PTU induced inhibition of total $\left[{ }^{3} \mathrm{H}\right]$ acetaminophen covalently bound to rat whole liver homogenates vs. total biliary excretion of $\left[{ }^{35} \mathrm{~S}\right] \mathrm{PTU}$ product as defined and separated by thin layer chromatography (TLC). Two groups of 10 phenobarbital pretreated rats each were administered 0 or $150 \mathrm{mg}\left[{ }^{35} \mathrm{~S}\right] \mathrm{PTU}(\mathrm{P}) .30 \mathrm{~min}$ later, the groups were each divided into two subgroups of five rats and treated with 0 or $750 \mathrm{mg} / \mathrm{kg}\left[{ }^{3} \mathrm{H}\right]$ acetaminophen (A). Bile was collected from each rat for $4 \mathrm{~h}$, after which the animals were killed and their whole liver homogenates were assayed for $\left[{ }^{3} \mathrm{H}\right]-$ acetaminophen covalent binding. Bile samples were applied to thin layer chromatography as noted in Fig. 6 and the total amount of ${ }^{35} \mathrm{~S}$ eluting as new product was counted. Results are depicted as mean $\pm S E$. The reduction in covalent binding resulting from PTU treatment $(108 \mathrm{nmol})$, which is the difference between the two bars on the left, approximates total biliary excretion of new [ $\left.{ }^{35} \mathrm{~S}\right] \mathrm{PTU}$ product $(116 \mathrm{nmol})$. This product was not found in rats treated with PTU alone. ${ }^{* P}$ $<0.05 ; * * P<0.001$.

microsomal drug metabolizing enzymes (28). Thus, the apparent protective effect of PTU could be ascribed to inhibition of reactive metabolite formation. However, we were unable to observe in vivo any effect of shortterm PTU treatment on hepatocyte microsomal drug metabolizing enzyme concentration, activity, or regenerating capacity, nor did we observe any inhibition of acetaminophen metabolic activation by PTU in vitro.

Thus, we examined the remaining possibility that PTU forms a conjugate with the reactive metabolite of acetaminophen. We were able to identify in liver homogenates from acetaminophen-treated mice, as well as in incubates of PTU with acetaminophen in the presence of liver microsomes and an NADPH-generating system, a new PTU product that could be distinguished clearly from unreacted PTU. The amount of new product formation in a microsomal incubation system was a function of PTU concentration but was not observed in the absence of acetaminophen. The physiologic significance of this new product was confirmed by our observation that the amount of PTU excreted as new product in vivo, presumably acetaminophen-PTU conjugate, correlated quite closely with the net decrease in acetaminophen covalent binding of hepatocyte macromolecules. We conclude therefore that PTU exerts a protective effect against acetaminophen toxicity by direct chemical reaction with its reactive metabolite, thereby preventing its covalent binding to macromolecules and resultant hepatocellular injury.

\section{ACKNOWLEDGMENTS}

We are grateful for the secretarial assistance of Anita Boesman, and technical advice of Dr. Joseph Reeve.

This work was supported by U. S. Public Health Service grant GM/CA 24987 and Veterans Administration Medical Research funds.

\section{REFERENCES}

1. Black, M. 1980. Acetaminophen hepatotoxicity.Gastroenterology. 78: 382-392.

2. Mitchell, J. R., D. J. Jollow, W. Z. Potter, D. C. Davis, J. R. Gillette, and B. B. Brodie. 1973. Acetaminopheninduced hepatic necrosis. I. Role of drug metabolism. J. Pharmacol. Exp. Ther. 187: 185-194.

3. Jollow, D. J., J. R. Mitchell, W. Z. Potter, D. C. Davis, J. R. Gillette, and B. B. Brodie. 1973. Acetaminopheninduced hepatic necrosis. II. Role of covalent binding in vivo. J. Pharmacol. Exp. Ther. 187: 195-202.

4. Potter, W. Z., D. C. Davis, J. R. Mitchell, D. J. Jollow, J. R. Gillette, and B. B. Brodie. 1973. Acetaminopheninduced hepatic necrosis. III. Cytochrome P-450 mediated covalent binding in vitro.J. Parmacol. Exp. Ther. 187: 203-210.

5. Mitchell, J. R., D. J. Jollow, W. Z. Potter, J. R. Gillette, and B. B. Brodie. 1973. Acetaminophen-induced hepatic necrosis. IV. Protective role of glutathione. J. Pharmacol. Exp. Ther. 187: 211-217.

6. Brodie, B. B., and J. Axelrod. 1948. The estimation of acetanilide and its metabolic products, aniline, $\mathrm{N}$-acetyl$p$-aminophenol and $p$-aminophenol (free and total conjugated) in biological fluids and tissues. J. Pharmacol. Exp. Ther. 94: 22-28.

7. Rollins, D. E., and Buckpitt, A. R. 1979. Liver cytosol catalyzed conjugation of reduced glutathione with a reactive metabolite of acetaminophen. Toxicol. Appl. Pharmacol. 47: 331-339.

8. Prescott, L. F., R. W. Newton, C. P. Swainson, N. Wright, A. R. W. Forrest, and H. Matthew. 1974. Successful treatment of severe paracetamol overdosage with cysteamine. Lancet. I: 588-592.

9. Prescott, L. F., J. Park, A. Ballantyne, P. Adriaenssens, and A. T. Proudfoot. 1977. Treatment of paracetamol (acetaminophen) poisoning with $N$-acetylcysteine. Lancet. II: 432-434.

10. Linscheer, W. G., K. L. Raheja, C. Cho, and N. J. Smith. 1980. Mechanism of the protective effect of propylthiouracil against acetaminophen (Tylenol) toxicity in the rat. Gastroenterology. 78: 100-107.

11. Israel, Y., H. Kalant, H. Orrego, J. M. Khanna, L. Videla, and J. N. Phillips. 1975. Experimental alcohol-induced hepatic necrosis: suppression by propylthiouracil. Proc. Natl. Acad. Sci. U. S. A. 72: 1137-1141.

12. Orrego, H., F. J. Charmichael, M. J. Phillips, H. Kalant, J. Khanna, and Y. Israel. 1976. Protection by propylthio- 
uracil against carbon tetrachloride-induced liver damage. Gastroenterology. 71: 821-826.

13. Orrego, H., H. Kalant, Y. Israel, J. Blake, A. Medline, J. G. Rankin, A. Armstrong, and B. Kapur. 1979. Effect of shortterm therapy with propylthiouracil in patients with alcoholic liver disease. Gastroenterology. 76: 105-115.

14. Yamada, T., and N. Kaplowitz. 1980. Propylthiouracil: a substrate for the glutathione $S$-transferases that competes with glutathione. J. Biol. Chem. 255: 3508-3513.

15. Lowry, O. H., N. J. Rosebrough, A. L. Farr, and R. J. Randall. 1951. Protein measurement with the Folin phenol reagent. J. Biol. Chem. 193: 265-275.

16. Buckpitt, A. R., D. F. Rollins, S. D. Nelson, R. B. Franklin, and J. R. Mitchell. 1977. Quantitative determination of the glutathione, cysteine, and $\mathrm{N}$-acetyl cysteine conjugates of acetaminophen by high-pressure liquid chromatography. Anal. Biochem. 83: 168-177.

17. Owens, C. W., and R. V. Belcher. 1965. A colorimetric micromethod for the determination of glutathione. Biochem. J. 94: 705-711.

18. Kaplowitz, N. 1977. Interaction of azathioprine and glutathione in the liver of rats. J. Pharmacol. Exp. Ther. 200: 279-286.

19. Fretthold, D., and I. Shunshine. 1978. Analysis of acetaminophen (Tylenol) by HPLC. In Altex Chromatogram. Altex Scientific Inc. 1: 3.

20. Omura, T., and R. Sato. 1964. The carbon monoxidebinding pigment of liver microsomes. I. Evidence for its hemoprotein nature. J. Biol. Chem. 239: 2370-2378.
21. Netter, K. J., and G. Seidel. 1964. An adaptively stimulated $O$-demethylating system in rat liver microsomes and its kinetic properties. J. Pharmacol. Exp. Ther. 146: 61-65.

22. Dehnen, W., R. Tomingas, and J. Ross. 1973. A modified method for the assay of benzo (a) pyrene hydroxylase. Anal. Biochem. 53: 373-383.

23. Williams, C. H. Jr., and H. Kamin. 1962. Microsomal triphosphopyridine nucleotide-cytochrome $\mathrm{C}$ reductase of liver. J. Biol. Chem. 237: 587-595.

24. Israel, Y., P. G. Walfish, H. Orrego, J. Blake, and H. Kalant. 1979. Thyroid hormones in alcoholic liver disease. Effect of treatment with 6-n-propylthiouracil. Gastroenterology. 76: 117-122.

25. Linscheer, W. G., K. L. Raheja, C. Cho, C. Lely, and J. Schmidt. 1980. Propylthiouracil (PTU) detoxification of glutathione depleting hepatotoxins. Gastroenterology. 78: 1209. (Abstr.)

26. Slattery, J. T., and G. Levy. 1979. Acetaminophen kinetics in acutely poisoned patients. Clin. Pharmacol. Ther. 25: $184-195$.

27. Galinsky, R. E., and G. Levy. 1979. Effect of $N$-acetylcysteine on the pharmacokinetics of acetaminophen in rats. Life Sci. 25: 693-700.

28. Hunter, A. L., and R. A. Neal. 1975. Inhibition of hepatic mixed function oxidase activity in vitro and in vivo by various amino-sulfur-containing compounds. Biochem. Pharmacol. 24: 2199-2205. 